\title{
EFFECTS OF THE NITROGEN SOURCE AND CONCENTRATION ON N FRACTIONS IN OLIVE SEEDLINGS
}

\author{
J.L. García, R. Sarmiento, A. Troncoso and C. Mazuelos
}

Instituto de Recursos Naturales y Agrobiología, Consejo Superior de Investigaciones CientificasAptdo 1052 E.P., 41080 Sevilla, Spain

\begin{abstract}
The effect of the source $\left(\mathrm{KNO}_{3},\left(\mathrm{NH}_{4}\right)_{2} \mathrm{SO}_{4}\right.$ and $\left.\mathrm{NH}_{4} \mathrm{NO}_{3}\right)$ and concentration (5, 10,20 and $30 \mathrm{mM} \mathrm{N}$ ) of inorganic nitrogen on total $\mathrm{N}$ incorporation and distribution into different fractions (ammoniacal, amino, amide and protein) has been determined in olive seedlings.

Increasing concentrations of the nitrogen source resulted in higher total $\mathrm{N}$ content in tissues, except for $\mathrm{KNO}_{3}$ at $10 \mathrm{mM} \mathrm{N}$. In addition, ammonium applications clearly increased the $\mathrm{N}$-amino and $\mathrm{N}$-ammoniacal fractions. Incorporation of $\mathrm{N}$ into $\mathrm{N}$ amide was not affected significantly by any treatment, and only $\mathrm{KNO}_{3}$ and $\mathrm{NH}_{4} \mathrm{NO}_{3}$ additions showed significant increasing concentrations of $\mathrm{N}$-protein fractions.
\end{abstract}

\section{Introduction}

Nitrate or ammonium ions are the major sources of nitrogen utilized by plants. Experiments with a number of plant species comparing nitrate and ammonium nutrition have shown that the $\mathrm{N}$ form supplied exerts a pronounced effect on both the growth and the chemical composition of the plant.

Previous studies in plants indicate that higher crop yields may be obtained with a mixture of nitrate and ammonium than with either source alone (Hageman, 1984; Olsen, 1986).

The nitrogen nutrition of explants of grape vine rootstocks (Stewart and Rhodes, 1977; Sarmiento et al., 1992) has revealed differential effects on shoot and callus development. Increasing ammonium resulted in a significant increase in number, size and $\mathrm{N}$ content of shoots, and decreased callus formation. An excess of ammonium, however, resulted in undesired shoots with low $\mathrm{K}$ content, and, in contrast, an adequate supply of $\mathrm{K}$ enhances ammonium utilization and thus improves yields, especially when a mixed ammonium-nitrate nutrition is supplied (Olsen, 1986).

The aim of the present work was to compare the influence of different $\mathrm{N}$ forms and their concentrations on the accumulation of major fractions (ammoniacal, amino, amide and protein) in olive seedlings.

\section{Material and methods}

Olive embryos, isolated as described previously (Cañas et al., 1987), were germinated and grown in vitro at $25{ }^{\circ} \mathrm{C}$ with a photoperiod of $16 \mathrm{~h}$ of light $\left(30 \mu \mathrm{E} \cdot \mathrm{m}^{-2} \cdot \mathrm{s}^{-1}\right)$.

Three different $\mathrm{N}$ salts, $\mathrm{KNO}_{3},\left(\mathrm{NH}_{4}\right)_{2} \mathrm{SO}_{4}$ and $\mathrm{NH}_{4} \mathrm{NO}_{3}$, at four different concentrations of $\mathrm{N}$ each $(5,10,20$ and $30 \mathrm{mM})$ were added to the basal medium, that was olive medium (OM) (Rugini, 1984), half-strength with $10 \mathrm{~g} / \mathrm{l}$ sucrose as carbon source, and without any nitrogen. In total, 480 seedlings were used, 40 for each treatment.

After 60 days growth, seedlings from each treatment were analysed. Total $\mathrm{N}$, ammoniacal $\mathrm{N}$, amino $\mathrm{N}$, amide $\mathrm{N}$ and protein $\mathrm{N}$ were determined according to Sarmiento et al. (1977). 


\section{Resuits and Discussion}

In general, the nitrogen source and concentration had a marked influence on $\mathrm{N}$ fractions: total $\mathrm{N}$, ammoniacal $\mathrm{N}$, amino $\mathrm{N}$, amide $\mathrm{N}$ and protein $\mathrm{N}$ (figure 1 ).

The increasing concentrations of $\mathrm{N}$ resulted in a higher assimilation of $\mathrm{N}$ by the plants as shown by the total $\mathrm{N}$ content. The increase was moderate for $\mathrm{KNO}_{3}$, more marked for $\left(\mathrm{NH}_{4}\right)_{2} \mathrm{SO}_{4}$, and maximal for $\mathrm{NH}_{4} \mathrm{NO}_{3}$. These data are in agreement, in general, with previous results in grape vine explants (Troncoso et al., 1990; Villegas et al., 1992; Sarmiento et al., 1992).

When $\mathrm{KNO}_{3}$ is used, $\mathrm{N}$-protein fraction is about $70 \%$ of total $\mathrm{N}$ content, while for ammonium salts treatments, this proportion falls to $45-50 \%$. In addition, in the case of $\mathrm{KNO}_{3}$ and $\mathrm{NH}_{4} \mathrm{NO}_{3}, \mathrm{~N}$-protein increases when increasing $\mathrm{N}$ applications, while for $\left(\mathrm{NH}_{4}\right)_{2} \mathrm{SO}_{4}$ this fraction remains virtually unaffected. Thus, it seems that nitrate applications result in higher production of proteins by the plants, especially when only nitrate is used.

The $\mathrm{N}$-amino fraction is higher for $\mathrm{NH}_{4} \mathrm{NO}_{3}$ and $\left(\mathrm{NH}_{4}\right)_{2} \mathrm{SO}_{4}$, and increases in proportion to total $\mathrm{N}$ accumulation when increasing $\mathrm{N}$ in the medium, indicating some/ accumulation of amino acids in the seedlings. However, this amino acid accumulation does not result in a significant increase in $\mathrm{N}$-protein fraction.

Provision of $\mathrm{KNO}_{3}$ did not alter ammoniacal N content, but ammonium applications resulted in significant increases in this fraction.

The $\mathrm{N}$-amide fraction does not show any important modification by any treatment during the 60 day culture period.

The less eficiency of the seedlings in using nitrate, as shown by the less $\mathrm{N}$ total content, indicates a highly controlled absorption process, probably related to the high energy requirement for nitrate assimilation through the nitrate reductase pathway (Stewart and Rhodes, 1977; Campbell, 1988).

Street and Sheat (1958) reviewed the absorption and availability of nitrate and ammonium in plants. They concluded that factors which effect carbohydrate levels and respiration rates also influence the uptake and assimilation of nitrate and ammonium. The assimilation of nitrate and ammonium involves the use of carbohydrates as carbon skeletons for organic $\mathrm{N}$ compounds and as sources for the respiratory release of energy for nitrate reduction and reductive amination. Assuming that nitrate assimilation requires the reduction of nitrate to ammonium, it would be expected that ammonium assimilation will be as fast or faster than nitrate assimilation, and thus deplete carbohydrate reserves faster.

Ammonium promoted a relatively marked accumulation of $\mathrm{N}$ in tissues, which might indicate a less regulated control of uptake than in the case of nitrate. The highest increase in total $\mathrm{N}$ was observed with $\mathrm{NH}_{4} \mathrm{NO}_{3}$, in agreement with Hagin et al. (1990).

The seedlings supplied with the highest concentrations of added ammonium (30 $\mathrm{mM}$ ) had symptoms of incipient toxicity, in agreement with reports for several plant species (Cox and Reisenauer, 1973; Polizotto et al., 1975; Goyal et al., 1982). The toxicity appears to influence growth of the tops and of the roots equally.

In conclusion, ammonium saits treatments produced higher incorporation of $\mathrm{N}$ by the seedlings than that obtained when only nitrate was used, the stimulation being especially marked with $\mathrm{NH}_{4} \mathrm{NO}_{3}$. With the highest concentrations of $\left(\mathrm{NH}_{4}\right)_{2} \mathrm{SO}_{4}$ symptoms of toxicity were observed. 


\section{References}

Campbell, W.H., 1988. Nitrate reductase and its role in nitrate assimilation in plants. Physiol. Plant. 74:214-219.

Cañas, L.A., Carramolino L., and Vicente M., 1987. Vegetative propagation of the olive tree from in vitro cultured embryos. Plant Science, 50:85-90.

Cox, W.J. and Reisenauer, H.M., 1973. Growth and ion uptake by wheat supplied nitrogen as nitrate, or ammonium, or both. Plant and Soil, 8:363-380.

Goyal, S.S., Lorens, O.A. and Huffaker, R.C., 1982. Inhibitory effects of ammoniacal nitrogen on growth of radish plants. I. Characterization of toxic effects of $\mathrm{NH}_{4}^{+}$on growth and its alleviation by $\mathrm{NO}_{3}$.. J. Amer. Soc. Hort. Sci. 107:125-129.

Hageman, R.H., 1984. Ammonium versus nitrate nutrition of higher plants. In: Nitrogen in Crop Production, R.D. Hauck (Egd.), Am. Soc. Agron. Madison WI, 67-85.

Hagin, J., Olsen, S.R. and Shaviv, A., 1990. Review of interaction of ammoniumnitrate and potassium nutrition of crops. J. Plant Nutr. 13:1211-1226.

Olsen, S.R., 1986. The role of organic matter and ammonium in producing high corn yields. In: The Role of Organic Matter in Modern Agriculture, Y. Chen and Y. Avnimelech (Eds.), Martinus Nijhoff Publishers, 29-54.

Polizotto, K.R., Wilcox, G.E. and Jones, C.M., 1975. Response of growth and mineral composition of potato to nitrate and ammonium nitrogen. J. Amer. Soc. Hort. Sci. 100:165-168.

Rugini, E., 1984. In vitro propagation of some olive (Olea europaea sativa L.). cultivars with different root-ability, and medium development using analytical data from developing shoots and embryos. Sci. Hort., 24:123-134.

Sarmiento, R., Catalina, L., Valpuesta, V. and González García, F., 1977. El metabolismo nitrogenado en árboles de Olea europea, var. Manzanillo, en relación con la floración. I. Estudio de las fracciones nitrogenadas orgánicas. An. Edaf. Agrob. 36:565-572.

Sarmiento, R., Villegas, A., Mazuelos, C., García, J.L. and Troncoso, A., 1992. Influence of the nitrogen source and concentration on $\mathrm{N}$ fractions and free amino acid levels of grape vine explants. Plant and Soil, 144:255-258.

Stewart, G.R. and Rhodes, D., 1977. Control of enzyme levels in the regulation of nitrogen assimilation. In: Regulation of Enzyme Synthesis and Activity in Higher Plants, H. Smith (Ed.), Academic Press, London, 1-22.

Street, H.E. and Sheat, D.E.G., 1958. The absorption and availability of nitrate and ammonia. Encyclopedia of Plant Physiology, 8:150-240.

Troncoso, A., Villegas, A., Mazuelos, C. and Cantos, M., 1990. Growth and mineral composition of grape-vine rootstocks cultured in vitro with different levels of ammonium nitrate. In: Plant Nutrition-Physiology and Applications, M.L. van Beusichem (Ed.), Kluwer Academic Publishers, Dordrecht, 653-654.

Villegas, A., Mazuelos, C. and Troncoso, A., 1992. Influence of $\mathrm{N}-\mathrm{NO}_{3}$ and $\mathrm{N}-\mathrm{NH}_{4}$ on the mineral composition of grape-vine rootstocks cultured in vitro. Acta Horticulturae, 300:119-121. 

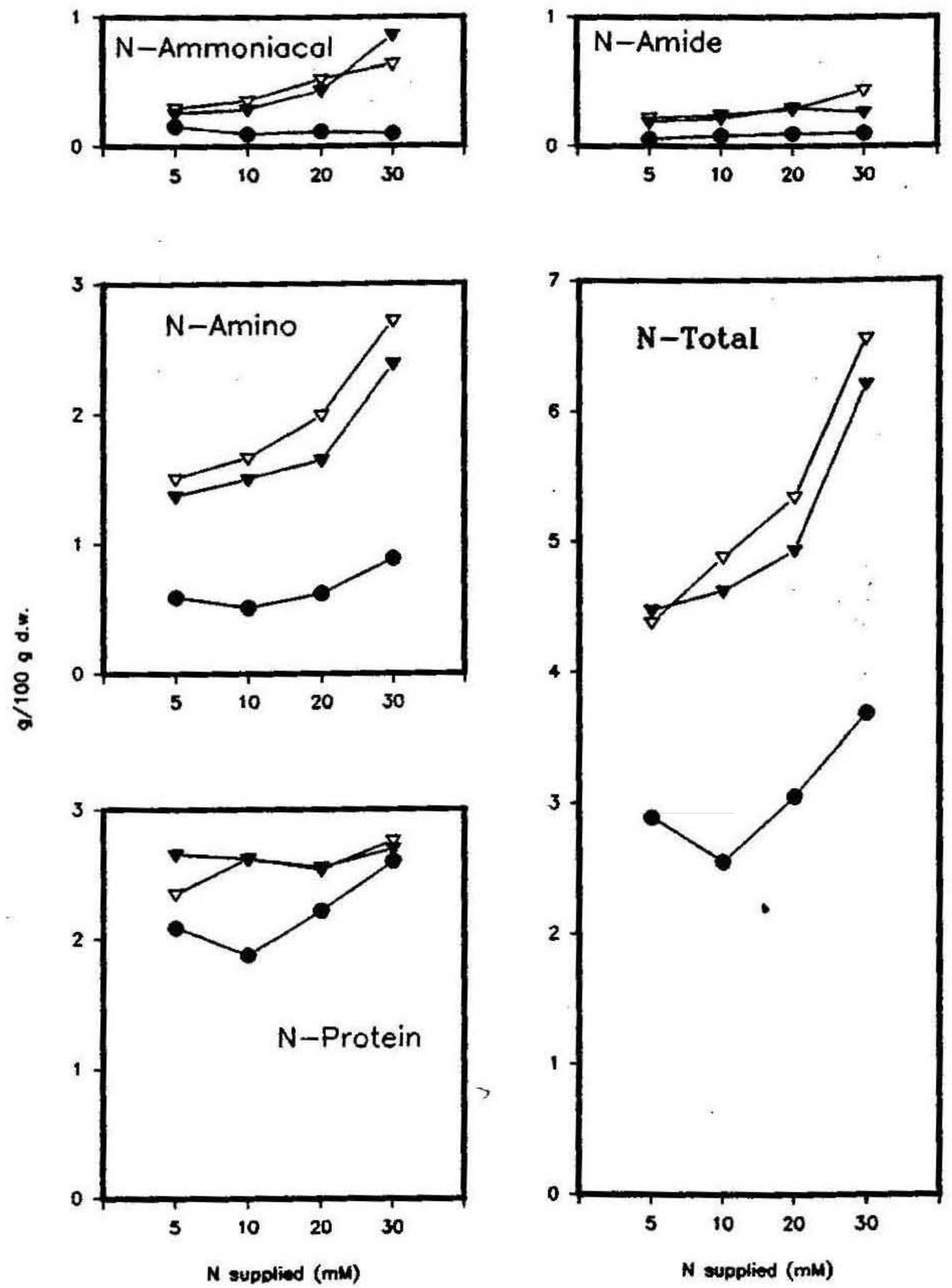

Figure 1 - Influence of the supply of different inorganic nitrogen sources on the distribution of $\mathrm{N}$ into various nitrogen fractions in olive seedlings.

$$
\begin{aligned}
& \text { - } \mathrm{KNO}_{3} \\
& \nabla \mathrm{NH}_{4} \mathrm{NO}_{3} \\
& -\left(\mathrm{NH}_{4}\right)_{2} \mathrm{SO}_{4}
\end{aligned}
$$

